University of Texas Rio Grande Valley

ScholarWorks @ UTRGV

Chemistry Faculty Publications and

Presentations

College of Sciences

$10-8-2020$

\title{
The efficient synthesis of d-xylulose and formal synthesis of Syringolide 1
}

\author{
Sudhakar Kalagara \\ Gabriel Orozco \\ Shizue Mito \\ The University of Texas Rio Grande Valley
}

Follow this and additional works at: https://scholarworks.utrgv.edu/chem_fac

Part of the Chemistry Commons

\section{Recommended Citation}

Kalagara, Sudhakar, Gabriel Orozco, and Shizue Mito. 2020. "The Efficient Synthesis of D-Xylulose and Formal Synthesis of Syringolide 1." Tetrahedron Letters 61 (41): 152321. https://doi.org/10.1016/ j.tetlet.2020.152321.

This Article is brought to you for free and open access by the College of Sciences at ScholarWorks @ UTRGV. It has been accepted for inclusion in Chemistry Faculty Publications and Presentations by an authorized administrator of ScholarWorks@ UTRGV. For more information, please contact justin.white@utrgv.edu,william.flores01@utrgv.edu. 


\title{
The efficient synthesis of D-xylulose and formal synthesis of Syringolide 1
}

\author{
Sudhakar Kalagara ${ }^{\text {a }}$, Gabriel Orozco ${ }^{\text {a }}$, and Shizue Mito*b \\ ${ }^{a}$ Department of Chemistry, the University of Texas at El Paso, El Paso, TX 79968, USA \\ ${ }^{b}$ Department of Chemistry, the University of Texas Rio Grande Valley, Edinburg, TX 78539, USA
}

\section{ARTICLE INFO}

\section{Article history:}

Received

Received in revised form

Accepted

Available online

Keywords:

D-xylulose

Syringolides

Protecting groups

Formal synthesis

Asymmetric dihydroxylation

\section{ABSTRACT}

\section{Introduction}

Syringolides 1 and 2 (1a and $\mathbf{1 b}$, Scheme 1) were isolated from $P$. syringae $p v$. tomato in 1993 by Sims et al. as the first nonproteinaceous specific elicitors of plant hypersensitive response (HR). ${ }^{1}$ They also proposed the biosynthetic pathway of Syringolides 1 from D-xylulose 2 and the corresponding $\beta$ ketoacids 3 (Scheme 1). ${ }^{2}$ Accordingly, the acylation of D-xylulose produces the ester $\mathbf{4}$ which, upon an intramolecular Knoevenagel condensation yields butenolide 5. Intramolecular Michael addition followed by hemiketalization then affords Syringolides 1. There have been several reports for the total synthesis of Syringolides. ${ }^{3,4}$ Most of them through the butenolide intermediate $\mathbf{5}$ using various alcohol protecting groups. ${ }^{4}$

Scheme 1. Proposed biosynthesis of Syringolides: (a) acylation, (b) Knoevenagel condensation, (c) Michael addition followed by hemiketalization

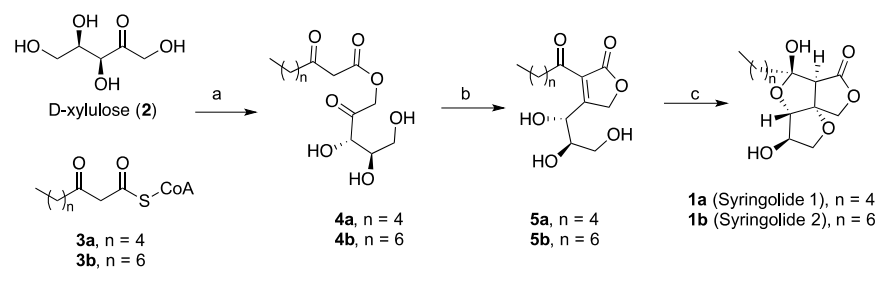

Scheme 2. Strategy of the synthesis of D-xylulose

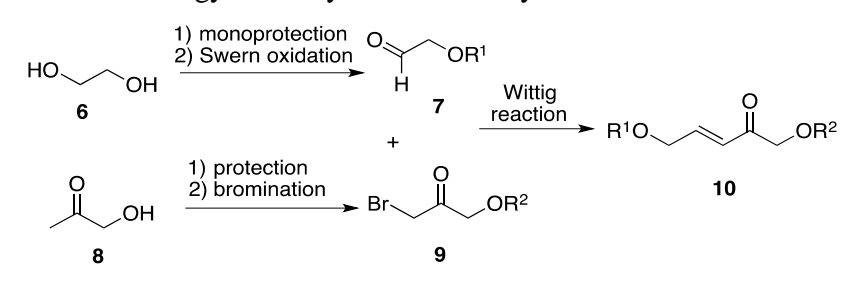

Rickards et al. synthesized Syringolides with the correct stereocenters using the biomimetic pathway, which starts with Dxylulose. ${ }^{3}$ Although D-xylulose is commercially available, its high cost is a drawback of this approach. To circumvent such disadvantage, several groups have employed other chiral starting materials, in lieu of D-xylulose, as the source of asymmetry. Some of the precursors are L-threitol, ${ }^{4 a}$ D-tartrate, $,{ }^{4 b}, 4 \mathrm{c} D$-xylofuranose, ${ }^{4 \mathrm{f}}$ $\mathrm{D}$-xylose, ${ }^{4 \mathrm{~g}}$ and D-arabinose. ${ }^{4 \mathrm{i}, 4 \mathrm{k}}$ Chemoenzymatic aldol reaction has also been reported ${ }^{4 \mathrm{j}}$ However, D-xylulose is one of the rare ketoses and plays an important role in several prokaryotic and eukaryotic metabolic pathways. Therefore, the generation of Dxylulose is still of interests to organic chemists. Isomerization of D-xylose to D-xylulose has been accomplished enzymatically with various carbohydrate isomerases during the past two decades. ${ }^{5}$ The enzymatic route is an efficient $\mathrm{C}-\mathrm{C}$ bond construction in the synthesis of xylulose, however, the enzymatic approaches have certain limitations in terms of substrate specificity and reaction conditions. Recently, isomerization with inorganic catalysts has been reported using Lewis acid catalysts as Sn-beta, ${ }^{6} \mathrm{CrCl}_{3},{ }^{7} \mathrm{Sn}$ $\mathrm{MFI},{ }^{8} \mathrm{MgF}_{2}{ }^{9}$ and $\mathrm{Al}_{2} \mathrm{O}_{3},{ }^{10}$ but low conversions are the problem. Although chemical synthesis of D-xylulose (as well as other carbohydrates) appears to be more challenging due to multiple hydroxyl groups and stereocenters in the molecule, ${ }^{11}$ it is beneficial to develop a new synthetic methodology to prepare D-xylulose. Herein we report the synthesis of D-xylulose via Wittig reaction and asymmetric dihydroxylation from the readily available

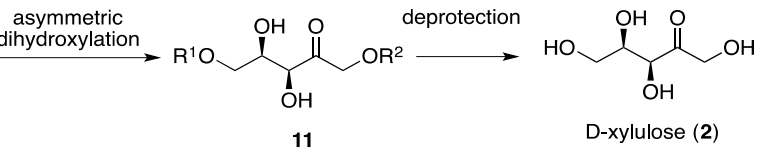

ethylene glycol (6) and hydroxyacetone (8) (Scheme 2). The proposed strategy is straightforward, and the choice of protecting 
groups is key to the success of this method. In addition, protected D-xylulose was applied in the formal synthesis of Syringolide 1 (1a).

\section{Results and Discussion}

\subsection{Synthesis of D-xylulose 2}

Scheme 3 shows the synthesis of the aldehydes 7 in Scheme 2. The monoprotection of ethylene glycol $\mathbf{6}$ with various protecting groups gave 12a-c in good yields (74-84\%). Swern oxidation of the protected alcohols $\mathbf{1 2} \mathbf{a}-\mathbf{c}$ yielded $\mathbf{7 a}-\mathbf{c}$ in $76-88 \%$.

Scheme 3.

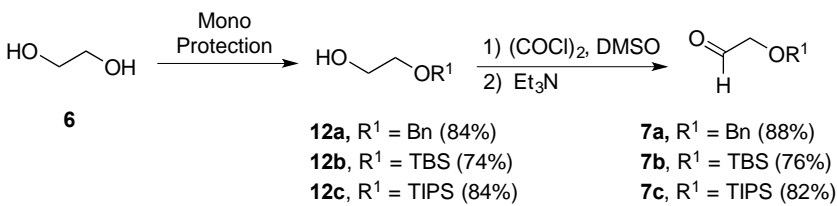

The $\alpha$-bromo ketone 9 shown in Scheme 2 was synthesized from hydroxyacetone 8 by protection followed by bromination (Scheme 4). Protection of $\mathbf{8}$ with TBS was carried out to produce 13a in $74 \%$ yield. However, $\alpha$-bromination of 13a using different brominating agents, such as $\mathrm{NBS}, \mathrm{Br}_{2}$, and $\mathrm{HBr}$, proved unsuccessful, despite the various reaction conditions studied. Acetylation of $\mathbf{8}$ was then carried out instead and gave 1-acetoxy2 -propanone $\mathbf{1 3 b}$ in $92 \%$ yield. $\alpha$-bromination of $\mathbf{1 3 b}$ afforded $\alpha$ bromoketone $9 \mathbf{b}$, which was used without further purification in the next step and gave the phosphonium bromide 14b in quantitative yield (2 steps).

\section{Scheme 4.}

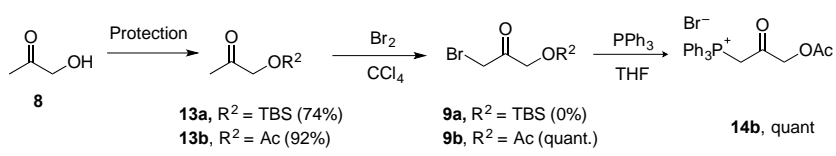

Wittig reaction ${ }^{12}$ between phosphonium salt $\mathbf{1 4 b}$ and several aldehydes $(\mathbf{7 a}-\mathbf{c})$ yielded the enones $(\mathbf{1 0 a}-\mathbf{c})$ in moderated to good yields (41-72\%) along with the deprotected enone 15 (Scheme 5). Conversion of $\mathbf{1 0}$ to $\mathbf{1 5}$ were also possible under mild basic conditions using $\mathrm{KHCO}_{3}$.

\section{Scheme 5.}

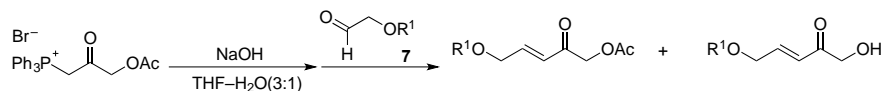

$$
\begin{aligned}
& \text { 14b }
\end{aligned}
$$

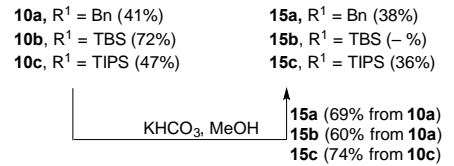

Dihydroxylation of enone $\mathbf{1 0 b}$ using $\mathrm{OsO}_{4}$ yielded $70 \%$ of $\mathbf{1 1 b}$ as a racemic mixture (Scheme 6). Asymmetric dihydroxylation of 10b using AD mix-beta was unsuccessful. A complex mixture of compounds was obtained with less than $50 \%$ of the enone reacted, even after extended reaction time. We observed that both of the acetyl and TBS protecting groups in $\mathbf{1 0 b}$ were not stable under the reaction conditions.

\section{Scheme 6.}

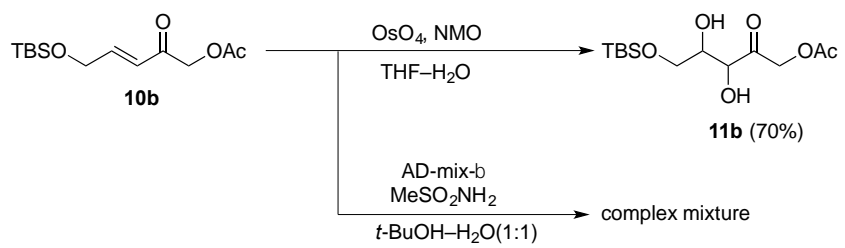

The $\alpha, \beta$-unsaturated compound $\mathbf{1 5 a}$ and $\mathbf{1 5 c}$, both without acetyl and TBS protecting groups, was thus chosen for an alternative synthesis (Scheme 7). Asymmetric dihydroxylation of 15a through the Sharpless reaction gave the desired protected D-xylulose 11a in $25 \%$ yield. The optical rotation of $11 a$ matched with the previously reported value. ${ }^{13}$ Part of the starting material 15a (18\%) could be recovered. In addition, aldehyde 7a was also isolated in $27 \%$ yield, possibly due to the retro-aldol reaction of 11a. When the $\alpha, \beta$-unsaturated compound 15c (TIPS protected) was employed, the asymmetric dihydroxylation yielded $78 \%$ of 11c (Scheme 7).

\section{Scheme 7.}

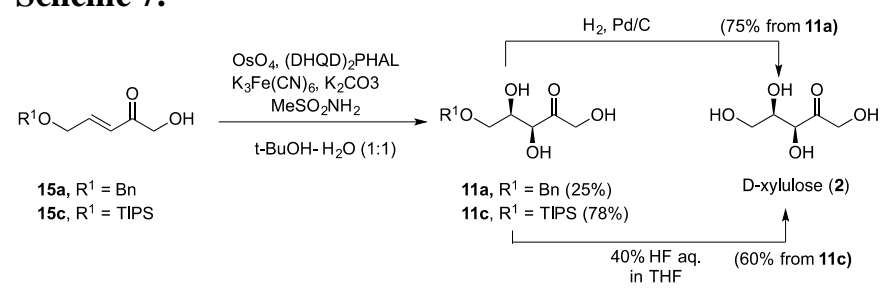

Debenzylation of 11a by hydrogenation gave D-xylulose 2 in $75 \%$ yield (Scheme 7). Similarly, the TIPS protected D-xylulose 11c was treated with aqueous $\mathrm{HF}$ in THF at room temperature, producing 2 in $60 \%$ yield. NMR data and optical rotation value of the product obtained from both pathways are in good agreement with those previously reported for D-xylulose. ${ }^{14}$

\subsection{Toward the formal synthesis of Syringolide 1 (1a)}

As mentioned above, there are several reports for the total synthesis of Syringolides $\mathbf{1} .^{3,4}$ In many of these routes, the common intermediates are protected $\mathbf{4}^{3}$ and/or $\mathbf{5}^{4}$ (Scheme 1). We hypothesize that derivatives of $\mathbf{4}$ or $\mathbf{5}$ could be obtained from intermediate $\mathbf{1 5}$ in the newly developed synthesis of D-xylulose (Scheme 8). Accordingly, Meldrum's adduct 16 was prepared from hexanoyl chloride and Meldrum's acid. ${ }^{3 a}$ The tricarbonyl compound 17 was obtained in $75 \%$ yield when treating $\mathbf{1 5 b}$ with 16. Attempts in dihydroxylation of $\mathbf{1 7}$ using $\mathrm{AD}-$ mix- $\beta$ reagent resulted in a complex mixture, possibly due to the lability of $\mathbf{1 7}$ under the reaction conditions. The enol of $\mathbf{1 7}$ is likely oxidized faster than the target $\mathrm{C}=\mathrm{C}$ double, as reported previously. ${ }^{4} \mathrm{e}$ Furthermore, the TBS group was removed under the basic reaction conditions.

\section{Scheme 8.}
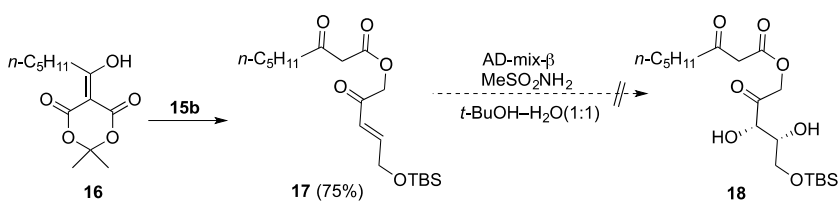

When the TIPS protected alcohol $\mathbf{1 5 c}$ was used, selective esterification of 15c with Meldrum's adduct $\mathbf{1 6}$ was not successful at high temperature, resulting in the formation of primary and secondary esters and a diester. The starting material $\mathbf{1 5 c}$ was fully recovered when the reaction was carried out at room temperature.

To circumvent the complications described above, we turned to compound 11c. Selective vicinal diol protection was successfully carried out with 2,2-DMP ${ }^{15}$ resulting in the acetonide 19 in $74 \%$ yield (Scheme 9). The acetonide 19 was then treated with Meldrum's adduct $\mathbf{1 6}$ under reflux to yield the tricarbonyl compound $\mathbf{2 0}$ in $70 \%$. Knoevenagel condensation was performed by simply mixing $\mathbf{2 0}$ with silica gel in ethyl acetate:hexanes (1:9 mixture), affording butenolide $\mathbf{2 1}$, which is a protected $\mathbf{5}$ in Scheme 1, in $72 \%$ yield. 21 is protected 5 in Scheme 1. Since it has been reported syntheses of Syringolide 1 from $\mathbf{5}$ with various protecting groups, ${ }^{4}$ we envision that deprotection of $\mathbf{2 1}$ followed by cyclization should yield Syringolide 1 (1a). 
Scheme 9.
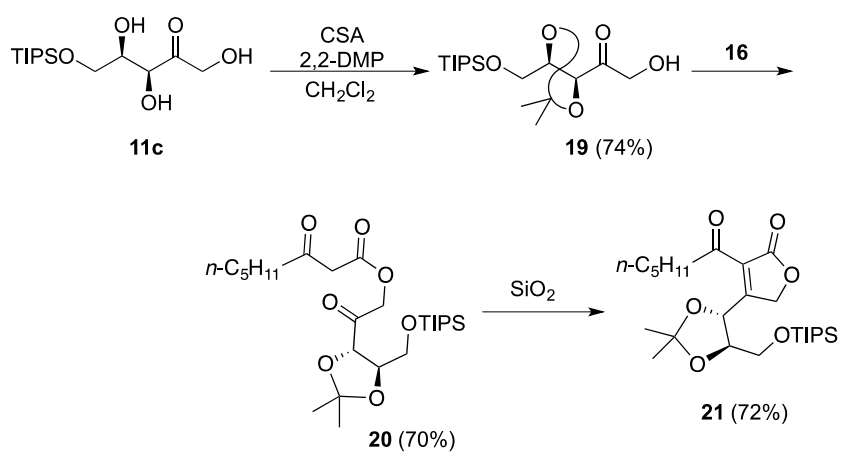

\section{Conclusions}

A novel, inexpensive synthetic strategy for the preparation of Dxylulose was developed using readily available starting materials such as hydroxyacetone and ethylene glycol. The choice of protecting groups is crucial in the success of this synthesis. A key intermediate in the synthesis of Syringolide 1 was successfully synthesized using the protected D-xylulose obtained through the newly developed methodology.

\section{Acknowledgments}

This work was supported by the College of Science Dean's Research Enhancement Fund at the University of Texas at El Paso (UTEP), and the Department of Chemistry at the University of Texas Rio Grande Valley is grateful for the generous support provided by a Departmental Grant from the Robert A. Welch Foundation (Grant No. BX-0048-20151106). S. K. was supported by the Department of Chemistry at UTEP and the portions of this work has appeared as his thesis dissertation (2015). ${ }^{16}$ The authors thank Salvando Rivera for synthesis of starting materials. Dr. Junha Jeon (University of Texas at Arlington) is greatly acknowledged for helpful discussions.

\section{References and notes}

1. Smith, M. J.; Mazzola, E. P.; Sims, J. J.; Midland, S. L.; Keen, N. T.; Burton, V.; Stayton, M. M. Tetrahedron Letters 1993, 34, 223.

2. Midland, S. L.; Keen, N. T.; Sims, J. J.; Midland, M. M.; Stayton, M. M.; Burton, V.; Smith, M. J.; Mazzola, E. P.; Graham, K. J.; Clardy, J. The Journal of Organic Chemistry 1993, 58, 2940.

3. (a) Henschke, J. P.; Rickards, R. W. Tetrahedron Letters 1996, 37, 3557; (b) Henschke, J. P.; Rickards, R. W. Journal of Labelled Compounds and Radiopharmaceuticals 1998, 41, 211; (c)Bennett, S. A.; Rickards, R. W. Tetrahedron Letters 2003, 44, 6927.

4. (a) Wood, J. L.; Jeong, S.; Salcedo, A.; Jenkins, J. The Journal of Organic Chemistry 1995, 60, 286; (b) Kuwahara, S.; Moriguchi, M.; Miyagawa, K.; Konno, M.; Kodama, O. Tetrahedron 1995, 51, 8809; (c) Kuwahara, S.; Moriguchi, M.; Miyagawa, K.; Konno, M.; $\quad$ Kodama, O. Tetrahedron Letters 1995, 36, 3201; (d) Honda, T.; Mizutani, H.; Kanai, K. The Journal of Organic Chemistry 1996, 61, 9374; (e) Ishihara, J.; Sugimoto, T.; Murai, A. Tetrahedron 1997, 53, 16029; (f) Yoda, H.; Kawauchi, M.; Takabe, K.; Hosoya, K. Heterocycles 1997, 45; (g) Zeng, C.-m.; Midland, S. L.; Keen, N. T.; Sims, J. J. The Journal of Organic Chemistry 1997, 62, 4780; (h) Yu, P.; Wang, Q.-G.; Mak, T. C. W.; Wong, H. N. C. Tetrahedron 1998, 54, 1783; (i) Chênevert, R.; Dasser, M. Canadian Journal of Chemistry 2000, 78, 275; (j) Chênevert, R.; Dasser, M. The Journal of Organic Chemistry 2000, 65, 4529; (k) Varvogli, A.-A. C.; Karagiannis, I. N.; Koumbis, A. E. Tetrahedron 2009, 65, 1048; (l) Navarro Villalobos, M.; Wood, J. L.; Jeong, S.; Benson, C. L.; Zeman, S. M.; McCarty, C.; Weiss, M. M.; Salcedo, A.; Jenkins, J. Tetrahedron 2009, 65, 8091.

5. (a) Concia, A. L.; Lozano, C.; Castillo, J. A.; Parella, T.; Joglar, J.; Clapés, P. Chemistry - A European Journal 2009, 15, 3808; (b)
Hochster, R. M.; Watson, R. W. Journal of the American Chemical Society 1953, 75, 3284; (c) Pronk, J. T.; Bakker, A. W.; van Dam, H. E.; Straathof, A. J. J.; Scheffers, W. A.; van Dijken, J. P. Enzyme and Microbial Technology 1988, 10, 537; (d) Roman, G. N.; Jansen, N. B.; Hsiao, H.-Y.; Tsao, G. T. Enzyme and Microbial Technology 1985, 7, 129; (e) Ståhlberg, T.; Woodley, J. M.; Riisager, A. Catalysis Science \& Technology 2012, 2, 291; (f) Wang, P. Y.; Johnson, B. F.; Schneider, H. Biotechnology Letters 1980, 2, 273.

6. (a) Chang, C.-C.; Wang, Z.; Dornath, P.; Je Cho, H.; Fan, W. RSC Advances 2012, 2, 10475; (b) Choudhary, V.; Pinar, A. B.; Sandler, S. I.; Vlachos, D. G.; Lobo, R. F. ACS Catalysis 2011, 1, 1724; (c) Holm, M. S.; Pagán-Torres, Y. J.; Saravanamurugan, S.; Riisager, A.; Dumesic, J. A.; Taarning, E. Green Chemistry 2012, 14,702 .

7. Choudhary, V.; Sandler, S. I.; Vlachos, D. G. ACS Catalysis 2012, 2, 2022.

8. (a) Cho, H. J.; Dornath, P.; Fan, W. ACS Catalysis 2014, 4, 2029; (b) Dapsens, P. Y.; Mondelli, C.; Jagielski, J.; Hauert, R.; PérezRamírez, J. Catalysis Science \& Technology 2014, 4, 2302.

9. (a) Agirrezabal-Telleria, I.; Guo, Y.; Hemmann, F.; Arias, P. L.; Kemnitz, E. Catalysis Science \& Technology 2014, 4, 1357; (b) Agirrezabal-Telleria, I.; Hemmann, F.; Jäger, C.; Arias, P. L.; Kemnitz, E. Journal of Catalysis 2013, 305, 81.

10. Ekeberg, D.; Morgenlie, S.; Stenstrøm, Y. Carbohydrate Research 2005, 340, 373.

11. (a) Glatthaar, C.; Reichstein, T. Helvetica Chimica Acta 1935, 18, 80; (b) Rabinsohn, Y.; Fletcher, H. G. The Journal of Organic Chemistry 1967, 32, 3452.

12. Seo, J.; Fain, H.; Blanc, J.-B.; Montgomery, J. The Journal of Organic Chemistry 1999, 64, 6060.

13. Bednarski, M. D.; Simon, E. S.; Bischofberger, N.; Fessner, W. D.; Kim, M. J.; Lees, W.; Saito, T.; Waldmann, H.; Whitesides, G. M. Journal of the American Chemical Society 1989, 111, 627.

14. Wu, Q.; Pan, Q.; Zhao, S.; Imker, H.; Serianni, A. S. The Journal of Organic Chemistry 2007, 72, 3081.

15. Hanessian, S.; Vakiti, R. R.; Dorich, S.; Banerjee, S.; Lecomte, F.; Del Valle, J. R.; Zhang, J.; Deschênes-Simard, B. Angewandte Chemie International Edition 2011, 50, 3497.

16. Sudhakar Kalagara, Ph.D dissertation, The University of Texas at El Paso (2015).

\section{Supplementary Material}

Electronic Supplementary Information (ESI) available: Experimental procedures and NMR spectra.

* Corresponding author.

Shizue Mito

Department of Chemistry

University of Texas Rio Grande Valley

1201 W University Dr. Edinburg, TX 78539

Tel.: +1-956-665-8740; e-mail: shizue.mito@utrgv.edu 